\title{
Free Trade, Customs Unions, and Transfers
}

\author{
Hideo Konishi* Carsten Kowalczyk ${ }^{\dagger} \quad$ Tomas Sjöström ${ }^{\ddagger}$
}

This Version: July 2003

JEL Classification Numbers: F00, F02, F10, F11, F13, F15

Keywords: Free Trade, Customs Unions, Free Trade Areas, GATT/WTO, Multilateralism, Transfers

Corresponding Author: Carsten Kowalczyk. The Fletcher School of Law and Diplomacy, Tufts University, MA 02155, Telephone: 617.627.5603, Fax: 617.627.3712, Email: carsten.kowalczyk@tufts.edu

\footnotetext{
*Department of Economics, Boston College, Chestnut Hill, MA 02467; Telephone: 617.552.1209; Email: hideo.konishi@bc.edu

$\dagger$ The Fletcher School of Law and Diplomacy, Tufts University, MA 02155; Telephone: 617.627.5603; Email: carsten.kowalczyk@tufts.edu

${ }^{\ddagger}$ Department of Economics, Pennsylvania State University, 608 Kern Graduate Building, University Park, PA 16802-3306; Telephone: 814.863.1295; Email: jts10@psu.edu
} 


\title{
Free Trade, Customs Unions, and Transfers
}

\author{
Abstract \\ All countries would agree to immediate global free trade if coun- \\ tries were compensated for any terms-of-trade losses with trans- \\ fers from countries whose terms-of-trade improve, and if customs \\ unions were required to have no effects on non-member countries. \\ Global free trade with transfers is in the core of a Kemp-Wan- \\ Grinols customs union game. (52 words)
}




\section{Introduction}

Even as the first multilateral trade negotiation round under the auspices of the World Trade Organization is underway, countries continue to establish new or expanded preferential trading arrangements. Provided for by the original GATT Article XXIV, these take the form of free trade areas, where members agree to eliminate all tariffs on mutual trade while leaving it up to each member which tariffs to quote on non-members, or they take the form of customs unions, where members not only eliminate tariffs on mutual trade but also agree to set common tariffs on their imports from non-members. Some of the recent agreements, and some of the agreements currently under negotiation, are customs unions and others are free trade areas; some are between countries of similar levels of per capita income, others are not; and some agreements are between economies of similar size, and others are between small and large countries. Until this date, more than 140 Article XXIV agreements have been notified to GATT or more recently to the WTO. Remarkably, about 70 of them have been notified within the last five years. ${ }^{1}$

Whether preferential trade arrangements are beneficial to the world trading system or not is a long-standing concern. On the one hand, they represent

\footnotetext{
${ }^{1}$ See www.wto.org.
} 
a violation of the fundamental GATT principle that members of GATT provide most-favored-nation treatment of imports from other GATT members, on the other hand, they may represent a way for some countries to liberalize faster or more extensively on their mutual trade than what might be possible within the context of multilateral rounds.

In this paper, we take a direct approach and ask whether going to global free trade immediately could be the outcome in a world where countries can form customs unions. We take some features of the world trading system as given, while we consider modified versions of others. The key features we take as given are that countries are able to liberalize preferentially with some other trading partners, and that multilateralism - and, in particular, global free trade - requires some sort of unanimous consent among the contracting parties. The key modifications we introduce are on the external tariffs of customs unions, and on global free trade. Specifically, we consider a revision of GATT Article XXIV requiring that when countries form customs unions they must set their common external tariffs such that there will be no effects on the aggregate trade flows of the customs union members with non-members, and hence no changes in the prices and economic welfare of 
non-members. ${ }^{2}$ We assume also that a proposal for, and a move to, global free trade comes with a fiscal mechanism that specifies transfers between national governments. These assumptions reflect important institutional aspects of the GATT/WTO, as well as what we believe could be productive features to analyze given the findings from existing research.

Our first building bloc is Ohyama-Kemp-Wan customs unions: In early work on customs unions, Jacob Viner (1950) showed that even though a customs union represents a reduction of trade barriers, and hence a move towards Pareto optimal global free trade, a customs union may reduce economic welfare if it induces members to import from high-cost rather than from low-cost sources. ${ }^{3}$ Franz Gehrels (1956-57), and Richard Lipsey (1957) pointed out that even in this case it is possible that a customs union raises economic welfare if there is sufficient substitution in consumption or in production. However, about 20 years later, a more sweeping result was established when Michihiro Ohyama (1972) and Murray Kemp and Henry Wan

\footnotetext{
${ }^{2}$ Leaving trade with non-member countries constant may also require taxing some of the custom union members' exports, which, as emphasized by Wilfred Ethier (2002), are currently not subject to significant multilateral discipline. Or it may require subsidizing some of the customs union exports. In this paper, we will assume that any policies required to leave customs unions' imports from and exports to non-members constant are feasible and admissible.

${ }^{3}$ Among other early contributions are Richard Lipsey and Kelvin Lancaster's (1956) discussion of customs unions and the theory of second best, and James Meade's (1955a,b) consideration of customs unions and distortions.
} 
(1976) demonstrated that it is possible to form customs unions that (a) set their common external tariffs such that no non-member country is affected (denoted by Jaroslav Vanek (1965) as the compensating external tariff), and that (b) redistribute income between the customs union members so that no member country loses and so that some member country gains from joining the customs union. It is an important corollary to this result, and one stressed by Ohyama, Kemp, and Wan, that global free trade can be reached through sequences of ever-expanding compensating customs unions such that no country in the world ever loses at any stage of any sequence and some country gains.

Somewhat surprisingly, there are some obvious and important questions about a world in which customs unions take this form that have not been asked in the literature: Which Ohyama-Kemp-Wan customs unions would actually form on the way to global free trade? And what would be the outcome if immediate global free trade were offered as an option in a world where customs unions were restricted to being of the Ohyama-Kemp-Wan type? We answer these questions in this paper.

To do so, we introduce two additional key features in our analysis: We assume a particular rule for how nations decide on policy outcomes, i.e., we 
specify an equilibrium concept for the multilateral trade policy game that we consider, and we assume that income transfers are feasible, not only between the residents in a country, but also between the governments of different countries.

The core is our second building bloc: It is a longstanding principle as well as practice in multilateral GATT rounds that any participant, or any group of participants, if objecting to a proposal for multilateral liberalization, can prevent the adoption of such a proposal. In other words, a proposal for multilateral trade liberalization is only adopted if the proposal is not blocked by any participant or group of participants. The collection of proposals or situations that are not blocked is sometimes called the core of the negotiations or of the policy game at hand. We maintain with Kowalczyk and Sjöström (1994) that the core is a natural solution concept for an inquiry into whether global free trade is a possible outcome of the world trading system as embodied in the rules, regulations, and practices of GATT/WTO.

There has been some research on the core in trade policy games: Raymond Riezman (1985) finds in a model of three symmetric countries that free trade may not be in the core because some countries may prefer to form a free trade area or a customs union. John Kennan and Riezman (1988) explore, in 
a two-country setting, under which conditions a welfare-maximizing country prefers tariffs to free trade, and they consider in Kennan and Riezman (1990) when groups of countries may form customs unions or free trade areas for the purpose of achieving a higher payoff than in free trade. These papers rule out explicitly any use of income transfers between nations, and therein lies an important reason why global free trade is blocked: If countries are asymmetric, if, for example, they are of different size, it is difficult to obtain global free trade since, as shown already by Harry Johnson (1953) in a two-country model, a sufficiently large country may be able to obtain higher welfare with a tariff even if its trade partner retaliates. ${ }^{4}$ But then, because global free trade is Pareto optimal, there would exist a payment from the country that loses from the tariff war to the country that gains from the tariff war that does not exceed what the latter country loses in economic welfare from giving up its tariffs, and that is smaller than what the former country gains from global free trade. The country losing from the tariff war is willing to offer that payment, and the country losing from free trade is willing to accept

\footnotetext{
${ }^{4}$ Inés Macho-Stadler, David Pérez-Castrillo, and Clara Ponsati (1995) consider the core in a three-country game with symmetric countries where countries set optimal tariffs but with policy preferences affected by interest groups. They too rule out any use of income transfers between nations, and find that global free trade may not be in the core.
} 
it in return for an agreement to trade freely. ${ }^{5}$ In a many-country world, Kowalczyk and Sjöström (1994) derive international transfers that support, as an outcome in the core, the multilateral cooperation required to eliminate all distortions. Their model is one of international trade in monopoly goods, and policies are price ceilings, not tariffs. It remains to be analyzed whether international transfers can be used to establish multilateral cooperation, and in particular global free trade, as an outcome in the core in a world of tariffs where countries have the option to form free trade areas or customs unions.

Our third building bloc is, therefore, international transfers with global free trade. Drawing on work by Jean-Michel Grandmont and Daniel McFadden (1972), Earl Grinols (1981), in the standard competitive model of international trade with tariffs, demonstrates that giving to each customs union member country its pre-integration trade vector is both feasible and ensures that no country loses from joining such a union. Kowalczyk and Sjöström (2000) show that the transfers proposed by Grinols also support multilateral policy cooperation as an outcome in the core in their monopoly trade model. However, it has not been considered whether the transfers proposed by Grinols, or any other transfers, have the property of enabling

\footnotetext{
${ }^{5}$ Kowalczyk (2000) shows how a small country might use transfers of income to obtain free trade agreements with large countries in a standard trade model.
} 
immediate global free trade in the standard competitive model with tariffs. While considering such transfers as taking place between the members of a customs union is a natural one - after all, some of the most prominent examples of such international income transfers are the structural and regional funds in the European Union - we do not believe that international transfers in the context of multilateral trade liberalization should be dismissed out of hand. For example, some programs of the International Monetary Fund and the World Bank link disbursements of funds, at least partially, to reform of the recipients' trade policies. ${ }^{6}$ And it may be difficult to rule out that international transfers might have played some, possibly limited, role in past GATT rounds, perhaps in the bilateral negotiations that at times underlie a multilateral agreement. But the main reason that we propose that it is useful at least to analyze international income transfers in the context of global free trade is that without them it has been difficult in theoretical work to generate global free trade as an outcome.

We proceed by considering a world where global free trade requires that no country or group of countries has a better feasible alternative, where customs unions are constrained to being of the Ohyama-Kemp-Wan type,

\footnotetext{
${ }^{6}$ The linkage between income transfers and trade policy is at times obtuse, for example due to the existence of other program objectives.
} 
and where international income transfers, whether within customs unions or in connection with global free trade, are those proposed by Grinols. ${ }^{7}$ In that world, we ask: Since international transfers are helpful in garnering the gains from customs unions, could they not be helpful also in realizing the gains from global free trade? Which customs unions would countries form if an option to go to global free trade immediately combined with income transfers were available to them? And which customs unions would countries form en route to global free trade in order to seek to improve their payoffs in a subsequent situation of global free trade.

Our answers are: If free trade with the transfers proposed by Grinols were an option, no Ohyama-Kemp-Wan customs unions would form. They would not form as a final alternative to global free trade, nor would they form en route to global free trade. Global free trade with Grinols transfers would be realized immediately. Global free trade with Grinols transfers is

\footnotetext{
${ }^{7}$ We focus in this paper on the transfers proposed by Grinols for two reasons: (i) they are the only transfers that ensure that no member loses from joining a Kemp-Wan customs union if customs union members exhibit no substitutability in consumption and production (Grinols (op.cit.)); (ii) they support multilateral cooperation as an outcome in the core of a policy game, albeit a different one than the one we consider in this paper (Kowalczyk and Sjöström (2000)). We do not exclude that for an arbitrary competitive world economy there could be other formulae for international income transfers than the one discussed by Grinols that might support global free trade as an outcome in the core, just as there are in the monopoly trade model. We do not consider this question in this paper.
} 
in the core of the trade policy game implied by Kemp-Wan-Grinols customs unions. ${ }^{8}$

We present the economic environment in section 2, and we introduce the restrictions on admissible customs unions, the criterion for multilateral agreements, and the transfer mechanism in section 3. We derive our results in section 4. In section 5, we discuss our use of global free trade with transfers as the reference situation, and we consider in section 6 points of critique and some implications from our findings. We conclude in section 7 .

\section{The Economy and Economic Welfare}

We consider a world economy where $n$ countries trade a finite number of goods $l$. We assume that in each country $i(i=1, \ldots, n)$, production and consumption possibilities are closed and convex, and that in each country $i$ there is a representative consumer with continuous, quasi-concave preferences expressed by a utility function $u^{i}\left(c^{i}\right)$, where $c^{i}$ is a vector of consumption goods, and where $u^{i}$ denotes the resulting level of utility. We denote by

\footnotetext{
${ }^{8}$ Konishi, Kowalczyk, and Sjöström (2003) prove that the core is non-empty with no restrictions on the rules for income transfers between customs union members when customs unions may have no effect on non-members.
} 
$p^{i}$ the vector of domestic prices that price-taking consumers and producers in country $i$ face, and by $p^{e}$ the vector of prices at which consumers and firms in that country trade internationally. We assume that any difference between the two price vectors would be caused by trade taxes $t^{i}$ levied by the government in country $i, t^{i}=p^{i}-p^{e}$, and that any tariff revenue is redistributed back to domestic consumers in lump-sum fashion.

Let $e^{i}\left(p^{i}, u^{i}\right)$ be an expenditure function. ${ }^{9} \quad$ We will be comparing the effects on the economic welfare of countries from proposed changes in trade policies. For two arbitrary economic situations, a pre-change situation $A$ and a post-change situation $B$, we will evaluate the change in economic welfare for country $i$ by considering the compensating variation for country $i$ as given by,

$$
\Delta \eta_{B, A}^{i}=e^{i}\left(p_{B}^{i}, u_{B}^{i}\right)-e^{i}\left(p_{B}^{i}, u_{A}^{i}\right)
$$

We define country $i^{\prime}$ s economic welfare as having increased if $u_{B}^{i}>u_{A}^{i}$, or, equivalently, if $\Delta \eta_{B, A}^{i}>0$.

Let $y^{i}$ be the vector of production in country $i$, and $m^{i}=c^{i}-y^{i}$ be country

\footnotetext{
${ }^{9}$ The expenditure function has the standard properties under local nonsatiation that it is non-decreasing, homogenous of degree one, concave and continuous in $p^{i}$, and increasing in $u^{i}$.
} 
$i^{\prime} s$ net trade vector, where net imports are positive and net exports negative entries. Evaluated at domestic prices $p^{i}$, balanced trade for country $i$ can be written as the requirement that spending equals all sources of income. For example, in post-change situation $B$, this budget constraint becomes

$$
e^{i}\left(p_{B}^{i}, u_{B}^{i}\right)=p_{B}^{i} y_{B}^{i}+\left(p_{B}^{i}-p_{B}^{e}\right) m_{B}^{i}+T_{B}^{i}
$$

where $p_{B}^{i} y_{B}^{i}$ is income from domestic production, $\left(p_{B}^{i}-p_{B}^{e}\right) m_{B}^{i}$ is redistributed tariff revenue, and $T_{B}^{i}$ is any other lump-sum income. ${ }^{10}$

Following Earl Grinols and Kar-yiu Wong (1991), substituting (2) into (1), and subtracting and adding $p_{B}^{i} y_{A}^{i}$, and adding and subtracting $p_{B}^{i} c_{A}^{i}$, yield

$\Delta \eta_{B, A}^{i}=p_{B}^{i}\left(y_{B}^{i}-y_{A}^{i}\right)+p_{B}^{i} y_{A}^{i}+\left(p_{B}^{i}-p_{B}^{e}\right) m_{B}^{i}+T_{B}^{i}+p_{B}^{i} c_{A}^{i}-e^{i}\left(p_{B}^{i}, u_{A}^{i}\right)-p_{B}^{i} c_{A}^{i}$

If the representative consumer in country $i$ exhibits substitution as the prices he or she faces change from situation $A$ to situation $B$, the minimum expenditure required to achieve the initial level of utility, $u_{A}^{i}$, falls as implied

\footnotetext{
${ }^{10}$ Obviously, a similar expression holds for state $A$. We state the budget constraint for state $B$ only, since it proves to be particularly useful in our analysis.
} 
by the consumption gains $S_{B, A(\gamma)}^{i}$, where

$$
S_{B, A(\gamma)}^{i}=p_{B}^{i} c_{A}^{i}-e^{i}\left(p_{B}^{i}, u_{A}^{i}\right) \geq 0
$$

If profit-maximizing producers adjust their production in response to new prices, they do so because the value of the post-change plans exceeds the prechange plans as reflected by the production gains $S_{B, A(\pi)}^{i}$, where

$$
S_{B, A(\pi)}^{i}=p_{B}^{i}\left(y_{B}^{i}-y_{A}^{i}\right) \geq 0
$$

It is convenient to define the sum of the consumption and production gains by

$$
S_{B, A}^{i}=S_{B, A(\gamma)}^{i}+S_{B, A(\pi)}^{i} \geq 0
$$

Substitution into (3), and using that $-p_{B}^{i}\left(c_{A}^{i}-y_{A}^{i}\right)=-p_{B}^{i} m_{A}^{i}$, (3) simplifies to,

$$
\Delta \eta_{B, A}^{i}=S_{B, A}^{i}+\left(p_{B}^{i}-p_{B}^{e}\right) m_{B}^{i}+T_{B}^{i}-p_{B}^{i} m_{A}^{i}
$$

This expression states that, evaluated at post-change domestic prices, 
the change in country $i^{\prime} s$ economic welfare is caused by any of four possible effects: (i) non-negative consumption and production gains $S_{B, A}^{i}$, (ii) redistributed tariff revenue $\left(p_{B}^{i}-p_{B}^{e}\right) m_{B}^{i}$, (iii) net transfers $T_{B}^{i}$, and (iv) a terms of trade effect (as implied by $\left.p_{B}^{i} m_{A}^{i}\right){ }^{11}$

We assume that country $i$ seeks to maximize its income, and hence, if presented with different options, will seek the option that maximizes its gains to income as given by (7).

\section{Customs Unions, the Core, and Transfers}

As motivated in the Introduction, we wish to explore whether global free trade can be the policy outcome in a world of international trade where (a) global free trade requires multilateral consensus in the sense that any country can refuse to endorse a proposal for multilateral trade liberalization

\footnotetext{
${ }^{11}$ Subtracting and adding $\left(p_{B}^{i}-p_{B}^{e}\right) m_{A}^{i}$, and subtracting $T_{A}^{i}$ and adding $p_{A}^{e} m_{A}^{i}$, (7) can be rewritten as $\Delta \eta_{B, A}^{i}=S_{B, A}^{i}+\left(p_{B}^{i}-p_{B}^{e}\right)\left(m_{B}^{i}-m_{A}^{i}\right)+\left(p_{B}^{i}-p_{B}^{e}\right) m_{A}^{i}+\left(T_{B}^{i}-T_{A}^{i}\right)-$ $p_{B}^{i} m_{A}^{i}+p_{A}^{e} m_{A}^{i}$

$=S_{B, A}^{i}+\left(p_{B}^{i}-p_{B}^{e}\right)\left(m_{B}^{i}-m_{A}^{i}\right)+t_{B}^{i} m_{A}^{i}+\left(T_{B}^{i}-T_{A}^{i}\right)-\left(t_{B}^{i}+p_{B}^{e}\right) m_{A}^{i}+p_{A}^{e} m_{A}^{i}$

$=S_{B, A}^{i}+\left(p_{B}^{i}-p_{B}^{e}\right)\left(m_{B}^{i}-m_{A}^{i}\right)+\left(T_{B}^{i}-T_{A}^{i}\right)-\left(p_{B}^{e}-p_{A}^{e}\right) m_{A}^{i}$.

The last expression decomposes the change in country $i$ economic welfare into the sum of consumption and production gains, changes in tariff revenue (a volume of trade effect), changes in transfers, and a terms of trade effect. For many purposes this expression is useful. (See Ronald Jones (1969) for a discussion of it for small changes.) For the particular questions that we consider in this paper, expression (7), slightly modified, is convenient.
} 
by maintaining its initial trade policies or, if some other countries are willing to do so, by forming a customs union with these countries, and where (b) international transfers of income between countries may be used between the members of a customs union to induce its formation, or between all the world's trading nations to induce global free trade. In this and in the following section we will derive an international trade policy game that capture these essential features.

We maintain that the core is the appropriate criterion for whether a proposal of multilateral free trade would be agreed or not. In standard cooperative game theory, the core is defined as the set of feasible allocations from which no coalition (subset of players) can find an allocation that (i) is attainable by the members of coalitions without any help from the outsiders, and (ii) is better for every member of the coalitions. It is a feature of this standard definition that, due to (i), the core of a cooperative game is applicable only if there are no spillovers across coalitions, that is, if the members of a coalition never care about which other coalitions form. ${ }^{12}$ This poses a challenge for the applicability of standard cooperative game theory to problems in international trade economics, where linkages between nations

\footnotetext{
${ }^{12}$ Kowalczyk and Sjöström (1994) construct a model of international monopoly trade with no spillovers.
} 
are important, and where, in general, changes in some countries' policies will affect the trade, and hence prices and economic welfare, of other countries. ${ }^{13}$ The fact that Ohyama-Kemp-Wan customs unions set compensating external tariffs imply that such customs unions have no effects on non-members. It follows that in a world where all customs unions must be of the OhyamaKemp-Wan type, the core of the implied cooperative trade policy game can be defined in the standard way. ${ }^{14}$

The formal definition of the core is as follows: A (feasible) allocation is a list of consumption and production vectors $\left(\bar{c}^{i}, \bar{y}^{i}\right)_{i \in N}$. Pick a coalition $C \subseteq N$ and a feasible suballocation within $C,\left(\tilde{c}^{i}, \tilde{y}^{i}\right)_{i \in C}$. We say that coalition $C$ blocks allocation $\left(\bar{c}^{i}, \bar{y}^{i}\right)_{i \in N}$ via suballocation $\left(\tilde{c}^{i}, \tilde{y}^{i}\right)_{i \in C}$, if and only if $u^{i}\left(\tilde{c}^{i}\right)>$ $u^{i}\left(\bar{c}^{i}\right)$ for all $i \in C$. The core is a collection of feasible allocations that are not blocked by any coalitional deviations. Under the Ohyama-Kemp-Wan

\footnotetext{
${ }^{13}$ If spillovers were possible, the coalition formation game would be difficult to analyze because the decision whether or not to join a customs union would be complicated by the need to predict which other customs unions would form, and solving for the implied external tariffs.

${ }^{14}$ Currently Article XXIV stipulates that "duties and other regulations on commerce" on trade with contracting parties that are not members of the free trade area or customs union "shall not on the whole be higher or more restrictive than the general incidence of the duties and regulations of commerce." As discussed by Kowalczyk and Wonnacott $(1991,1992)$ it is quite possible that a customs union satisfying this requirement either wishes to increase or decrease its trade with non-members. The former would be what they define as a complement bloc and the latter what they define as a substitute bloc. By leaving trade with non-members constant, the Ohyama-Kemp-Wan customs union is a neutral bloc.
} 
customs unions, feasible allocations for each customs union (coalition) $C$ are not affected by what the rest of countries do (i.e., whether they form other customs unions or not).

What are feasible suballocations for customs union $C$ ? In abstract cooperative game theory, we can assign any set of feasible suballocations for each $C$ including the transferable utility case in which any kind of transfers among the members of $C$ are allowed. However, in real world applications, we can be more realistic by either allowing no transfer or by imposing a specific transfer rule.

As we discussed in the Introduction, both the negative results on the ability to obtain global free trade in the absence of international transfers by Johnson (op. cit.), Riezman (op. cit.) and Kennan and Riezman (1988, 1990), and the positive results on how international transfers may be necessary to induce world-wide policy cooperation by Kowalczyk and Sjöström $(1994,2000)$ lead us to maintain that at least the possibility of international income transfers in conjunction with global free trade must be provided for in an analysis of whether global free trade can be in the core. More concretely, we assume that the type of transfer rule proposed by Grinols (op. cit.), to give customs union members their pre-change trade vector, not only 
be applied between the members of a customs union, but be generalized to be applied to all the world's nations if the grand coalition of global free trade were to form.

Denoting the initial, pre-change situation as the status quo, and indicating it by subscript $S Q$, we thus assume that any proposal to form a OhyamaKemp-Wan customs union, or a proposal for global free trade, comes with a requirement that the transfers $T_{B}^{i}$, which we will denote as Grinols transfers when they are given by the following expression (8), be executed either between the members of the customs union or, if global free trade is proposed, between all the world's trading nations, ${ }^{15}$

$$
T_{B}^{i}=p_{B}^{i} m_{S Q}^{i}
$$

As a short-hand, we define the notion of a Kemp-Wan-Grinols customs union: ${ }^{16}$

Definition 1 A Kemp-Wan-Grinols customs union $(K W G)$ is an agreement

\footnotetext{
${ }^{15}$ Kowalczyk and Sjöström (2000) denote the transfers given by (8) Grinols transfers to distinguish them from a different formula for transfers, derived in Kowalczyk and Sjöström (1994), which they label as Shapley transfers. While denoting (8) as Grinols transfers is convenient, we recognize that Grandmont and McFadden (op. cit.) discuss them.

${ }^{16} \mathrm{We}$ choose this name for convenience. The work and names of Vanek and Ohyama are obviously vastly significant for this research.
} 
between a subset of the world's nations to (a) eliminate all tariffs on mutual trade; (b) set their compensating common tariffs on trade with non-members; and (c) apply Grinols transfers between member countries.

\section{The Trade Policy Game and Results}

We know from existing work that global free trade can emerge at the end of expanding Kemp-Wan-Grinols customs unions. But what if a proposal of going to global free trade with Grinols transfers in one step were proposed? Would it pass in the sense of not being blocked, or would some countries prefer to form a Kemp-Wan-Grinols customs union and stay there? And what if countries have the option of forming a Kemp-Wan-Grinols customs union on the way to global free trade with Grinols transfers? Might some countries then wish to use such customs unions to improve the payoffs they would ultimately receive when in global free trade with Grinols transfers? We will now answer these questions. We do so by analyzing a trade policy game where countries consider four options - the initial situation of arbitrary tariffs, which we will denote the status quo $(S Q)$, immediate global free trade with Grinols transfers $(F T G)$, membership of a Kemp-Wan-Grinols 
customs union $(K W G)$, or forming a Kemp-Wan-Grinols customs union, and possibly expand it, before arriving at global free trade with Grinols transfers $(K W F T G)$. We assume that each country prefers and seeks the option that yields the highest income to it or, equivalently, the largest income gain relative to the status quo, and that a country, when facing choices, blocks low-paying options if it can obtain higher-paying ones. Since we require that any policy change, unilateral or the forming of a customs union, must leave non-participants unaffected, remaining at the status quo is a unilateral decision for any country, and hence is always feasible. Thus, the core of the customs union game is defined relative to the status quo.

We proceed by comparing the payoffs to individual nations from the four options $S Q, F T G, K W G$, and $K W F T G$.

Substituting (8) into (7), we get the following useful expression:

$$
\Delta \eta_{B, A}^{i}=S_{B, A}^{i}+\left(p_{B}^{i}-p_{B}^{e}\right) m_{B}^{i}+p_{B}^{i} m_{S Q}^{i}-p_{B}^{i} m_{A}^{i}
$$

Proposition 1 Any country prefers global free trade with Grinols transfers to the status quo.

Proof. Let $A=S Q$ and $B=F T G$ in equation (9). Since, in free trade, 
$p_{B}^{i}=p_{B}^{e},(9)$ reduces to $\Delta \eta_{F T G, S Q}^{i}=S_{F T G, S Q}^{i} \geq 0$, with strict inequality if $p_{F T G}^{e} \neq p_{S Q}^{i}$. To see that Grinols transfers are feasible, add the transfers in (8) across all nations in $N$ to obtain $\sum_{i \in N} T_{F T G}^{i}=\sum_{i \in N} p_{F T G}^{e} m_{S Q}^{i}=$ $p_{F T G}^{e} \sum_{i \in N} m_{S Q}^{i}=0$, where the last equality reflects world-wide materials balance. Hence, $F T G$ is not blocked by $S Q$, while $S Q$ is blocked by FTG.

Evaluated at post-change free-trade prices, there are no tariff revenue effects in expression (9) when countries move to global free trade. There are, however, consumption and production gains if domestic prices faced by consumers and firms change. Finally, there are no terms-of-trade effects since Grinols transfers neutralize them: Subtracting $p_{S Q}^{e} m_{S Q}^{i}=0$ from the Grinols transfers in (8) yields, when situation $B$ is $F T G$,

$$
T_{F T G}^{i}=\left(p_{F T G}^{e}-p_{S Q}^{e}\right) m_{S Q}^{i}
$$

This is positive if country's $i$ 's terms of trade worsen from moving from the status quo to global free trade, and it is negative if country $i$ 's terms of trade improve. Thus, Grinols transfers compensate countries for any terms of trade losses from multilateral free trade by taxing the countries that experience terms of trade gains from multilateral free trade. Since the aggregate income 
effects from terms of trade changes are zero, Grinols transfers are feasible.

Proposition 2 For any potential Kemp-Wan-Grinols customs union (KWG), there is at least one member country that prefers global free trade with Grinols transfers (FTG) to membership of that potential Kemp-Wan-Grinols customs union $(K W G)$.

Proof. Let $A=K W G$ and $B=F T G$ in (9), and let $\Delta w \equiv \sum_{i \in C} \Delta \eta_{F T G, K W G}^{i}$ denote the aggregate difference in economic welfare of countries in KempWan-Grinols customs union $C$ between $K W G$ and $F T G$. We can show that $F T G$ is a potential Pareto improvement for countries in $C$ over $K W G$, i.e., $\Delta w \geq 0$, with strict inequality if there is some country $i \in C$ such that $p_{F T G}^{e} \neq p_{K W G}^{i}$

Let $m_{S Q}^{i j}$ be the vector of country $i$ 's net trade with country $j$ in the status $q u o$, and let $m_{K W G}^{i j}$ be the vector of country $i$ 's net trade with country $j$ in an arbitrary Kemp-Wan-Grinols customs union where countries $i$ and $j$ are 
members. Then,

$$
\begin{aligned}
\Delta w= & \sum_{i \in C}\left[S_{F T G, K W G}^{i}+p_{F T G}^{e}\left(m_{S Q}^{i}-m_{K W G}^{i}\right)\right] \\
= & \sum_{i \in C} S_{F T G, K W G}^{i}+p_{F T G}^{e} \sum_{i \in C}\left(m_{S Q}^{i}-m_{K W G}^{i}\right) \\
= & \sum_{i \in C} S_{F T G, K W G}^{i}+p_{F T G}^{e} \sum_{i \in C}\left(\sum_{j \in N, j \neq i} m_{S Q}^{i j}-\sum_{j \in N, j \neq i} m_{K W G}^{i j}\right) \\
= & \sum_{i \in C} S_{F T G, K W G}^{i} \\
& +p_{F T G}^{e} \sum_{i \in C}\left[\left(\sum_{j \in C, j \neq i} m_{S Q}^{i j}-\sum_{j \in C, j \neq i} m_{K W G}^{i j}\right)+\left(\sum_{k \in N \backslash C} m_{S Q}^{i k}-\sum_{k \in N \backslash C} m_{K W G}^{i k}\right)\right]
\end{aligned}
$$

By definition, $m_{K W G}^{i j}=-m_{K W G}^{j i}$ and $m_{S Q}^{i j}=-m_{S Q}^{j i}$ for all $i, j \in C$ with $i \neq j$. And since $C$ is a Kemp-Wan-Grinols customs union, its aggregate trade with non-members would be unaffected compared to the status quo, so $\sum_{i \in C}\left[\left(\sum_{k \in N \backslash C} m_{S Q}^{i k}-\sum_{k \in N \backslash C} m_{K W G}^{i k}\right)\right]=0$.

It follows that,

$$
\Delta w=\sum_{i \in C} S_{F T G, K W G}^{i} \geq 0
$$

This implies that, if there is some country $i \in C$ such that $p_{F T G}^{e} \neq p_{K W G \text {, }}^{i}$ then $\Delta w>0$ holds, and there is at least one potential member country of $K W G$ whose welfare is higher at $F T G$ than at $K W G$. Hence, $F T G$ is not blocked by $K W G$. 
We have shown that if global free trade with Grinols transfers is offered as an option, the world would not get stuck in a situation of Kemp-WanGrinols customs unions. Ohyama (op. cit.) and Kemp and Wan (op. cit.) also argued that the world would not get stuck in Kemp-Wan-Grinols customs unions, but their reason is different from ours: In their discussion, once a Kemp-Wan-Grinols customs union has been formed, it would choose to admit additional members since doing so can be done without harming any countries in the world and with gains to some. Our result states that not even the first Kemp-Wan-Grinols customs union would form if global free trade with Grinols transfers is presented as an option since some potential member of that customs union would be better off at free trade with Grinols transfers than as a member of the proposed customs union.

To explore further the reason behind this result, suppose the world consists of only three countries, 1,2 , and 3 , and suppose that countries 1 and 2 consider forming a Kemp-Wan-Grinols customs union. The sources of joint gains to countries 1 and 2 from doing so are the consumption and production gains from eliminating their intra-union tariffs. If there are potential gains to countries 1 and 2 from more trade with country 3 , i.e., if the common external tariff distorts, then global free trade represents a potential Pareto 
improvement for countries 1 and 2 over a Kemp-Wan-Grinols customs union. Global free trade with Grinols transfers relative to the status quo would not allow country 3 to gain from global free trade with Grinols transfers at the expense of its trading partners 1 and 2; in other words, global free trade with Grinols transfers guarantees that countries 1 and 2 jointly would gain more than they would gain from forming a Kemp-Wan-Grinols customs union, and hence at least one of countries 1 and 2, and possibly both, would block a Kemp-Wan-Grinols customs union between countries 1 and 2 .

We consider next whether some groups of countries might be able to agree to use Kemp-Wan-Grinols customs unions in order to improve their payoffs in a subsequent situation of free trade with Grinols transfers.

Proposition 3 For any potential Kemp-Wan-Grinols customs union followed by a move to global free trade with Grinols transfers (KWFTG), there is at least one member country that prefers to go directly to global free trade with Grinols transfers (FTG) to membership of that potential Kemp-WanGrinols customs union followed by global free trade with Grinols transfers (KWFTG).

Proof. Let $A=K W F T G$ and $B=F T G$ in (9). Analogous to the proof of Proposition 2, let $\Delta w \equiv \sum_{i \in C} \Delta \eta_{F T G, K W F T G}^{i}$ denote the aggregate 
difference in economic welfare of countries in Kemp-Wan-Grinols customs union $C$ between $K W F T G$ and $F T G$. We can show that $F T G$ is a potential Pareto improvement for countries in $C$ over $K W F T G$, i.e., that $\Delta w \geq 0$, with strict inequality if there is some country $i \in C$ such that $p_{F T G}^{e} \neq p_{K W F T G}^{i}$.

Let $m_{K W F T G}^{i j}$ be the vector of country $i$ 's net trade with country $j$ in a situation of global free trade with Grinols transfers arrived at after countries $i$ and $j$ have been members of some Kemp-Wan-Grinols customs union. Then,

$$
\begin{aligned}
\Delta w & =\sum_{i \in C}\left[S_{F T G, K W F T G}^{i}+p_{F T G}^{e}\left(m_{S Q}^{i}-m_{K W F T G}^{i}\right)\right] \\
& =\sum_{i \in C} S_{F T G, K W F T G}^{i}+p_{F T G}^{e} \sum_{i \in C}\left(m_{S Q}^{i}-m_{K W F T G}^{i}\right) \\
& =\sum_{i \in C} S_{F T G, K W F T G}^{i}+p_{F T G}^{e} \sum_{i \in C}\left(\sum_{j \in N, j \neq i} m_{S Q}^{i j}-\sum_{j \in N, j \neq i} m_{K W F T G}^{i j}\right)
\end{aligned}
$$

By definition, $m_{K W F T G}^{i j}=-m_{K W F T G}^{j i}$ and $m_{S Q}^{i j}=-m_{S Q}^{j i}$ for all $i, j \in C$ with $i \neq j$. Hence $\sum_{i \in C} \sum_{j \in N, j \neq i} m_{S Q}^{i j}=\sum_{i \in C} \sum_{j \in N, j \neq i} m_{K W F T G}^{i j}=0$, and it follows that,

$$
\Delta w=\sum_{i \in C} S_{F T G, K W F T G}^{i} \geq 0
$$

This implies that, if there is some country $i \in C$ such that $p_{F T G}^{e} \neq p_{K W F T G}^{i}$, 
then $\Delta w>0$ holds, and there is at least one potential member country of $K W F T G$ whose welfare is higher at $F T G$ than at $K W F T G$. Hence, FTG is not blocked by KWFTG.

One might believe that if nations know that a proposal of global free trade with Grinols transfers becomes an option after they have formed customs unions, then some of them might seek to form such customs unions to manipulate their positions in order to obtain higher payoffs in global free trade. We have shown that if customs unions are restricted to being KempWan-Grinols, then customs unions will not be used for this purpose. As the proof indicates, the reason behind this result is quite similar to the reason why a group of nations could not agree to form a Kemp-Wan-Grinols customs union and stay there. Consider again a world of only countries 1, 2, and 3. Since we require that the income transfers are defined relative to the status quo, countries 1 and 2 cannot use a Kemp-Wan-Grinols customs union to manipulate the size of any net transfer from country 3. But then the remaining reasoning is analogous to that underlying Proposition 2: Since global free trade (with Grinols transfers) is Pareto optimal, any gains to one potential customs union member from deviating from global free trade with Grinols transfers would come not at the expense of the non-member coun- 
try but at the expense of the potential customs union partner. The latter therefore blocks the "going to global free trade with Grinols transfers via a Kemp-Wan-Grinols customs union" proposal.

We have shown that global free trade with Grinols transfers is not blocked by the status quo, or by forming and remaining in a Kemp-Wan-Grinols customs union, or by forming a Kemp-Wan-Grinols customs union en route to global free trade with Grinols transfers. Recalling our earlier discussion of the core, we conclude with the main result of the paper:

Theorem 1 If free trade with Grinols transfers is proposed then, whether proposed as final alternatives or as a means to achieve higher free trade payoffs for their members, Kemp-Wan-Grinols customs unions would not be observed in the standard competitive model of international trade. Free trade with Grinols transfers is in the core of a Kemp-Wan-Grinols customs union game.

\section{On Global Free Trade As the Reference}

Our main result is remarkably strong. In part, this is due to our having introduced global free trade with transfers as the point of reference, i.e., as 
the situation to be blocked.

Consider again a simple example with countries 1, 2, and 3, and suppose, for illustration, that countries 1 and 2 are considering whether to form a Kemp-Wan-Grinols customs union. We showed that collectively countries 1 and 2 are better off at free trade with Grinols transfers than at the KempWan-Grinols customs union since, relative to the status quo, the sum of their gains in economic welfare from moving to global free trade with Grinols transfers exceeds the sum of their gains from forming a Kemp-WanGrinols customs union. If each of countries 1 and 2 is better off at free trade with Grinols transfers than at the Kemp-Wan-Grinols customs union, then each country would prefer global free trade with Grinols transfers to the Kemp-Wan-Grinols customs union, and the Kemp-Wan-Grinols customs union would be blocked by each potential partner country. This is not controversial.

But what if the gains to countries 1 and 2 from global free trade with Grinols transfers relative to forming a Kemp-Wan-Grinols customs union with each other are not evenly distributed between countries 1 and 2? In particular, what if country 2's payoff in $F T G$ exceeds its payoff from a $K W G$ customs union with country 1 , while country 1 's payoff in a $K W G$ customs 
union with country 2 exceeds country 1's payoff in FTG?

In our analysis, we have assumed that if any country prefers $F T G$ to membership of some proposed $K W G$ customs union, then the proposed $K W G$ customs union with that country as a member fails to form. So, if country 2 prefers $F T G$ to a $K W G$ customs union with country 1 , then $F T G$ wins the day even if country 1 prefers $K W G$ with country 2 to $F T G$. But could one not argue that since country 1 prefers $K W G$ with country 2 to $F T G$, country 1 would block FTG? After all, while country 1 cannot form a $K W G$ customs union with country 2 without country 2's consent, neither can country 2 obtain FTG without country 1's consent. Why would this situation not lead to a stand-off where country 1 insists on a $K W G$ customs union with country 2, while country 2 insists on $F T G$ which requires cooperation with all countries, including with country 1 ? If country 1 were a relatively large or powerful nation in the world economy, and if country 2 were a relatively small or weak one, would it be reasonable - or realistic - to assume that country 2 has its way with FTG being the outcome?

The most significant reason for using global free trade with transfers as the reference is that non-discrimination and most-favored-nation treatment are the cornerstones of the General Agreement on Tariffs and Trade, as well as of 
the World Trade Organization. From the perspective of the GATT/WTO, free trade areas and customs unions, as provided in Article XXIV, are offered as exceptions to these principles - free trade areas and customs unions are intended to be aberrations in the process of multilateral liberalization. We would thus argue that the letter and intent, and indeed the ideology, of GATT/WTO favor our approach of treating global free trade rather than preferential trade arrangements as the point of reference.

An argument against using global free trade with transfers as the reference is that it may be easier to negotiate trade liberalization with only a few partners in a customs union than with many countries in a multilateral round. However, our model does not incorporate negotiation costs, and, in addition, Kemp-Wan-Grinols customs unions require the calculation of compensating external tariffs, a potentially challenging task requiring the forecasting of the changes in extra-union trade flows as customs union members liberalize and the calculating of the changes in the external tariffs that would revert these extra-union flows to their initial levels. Since the Grinols transfers are the initial trade flows, whether the consideration is free trade with Grinols transfers or Kemp-Wan-Grinols customs unions, the zero tariffs would in fact imply that global free trade with transfers is easier to propose and to put 
in place than the more complicated-to-calculate Kemp-Wan-Grinols customs unions.

Another argument against using global free trade with transfers as the reference is that, under some circumstances, doing so could have the implication of favoring a small or relatively weak nation over a large or relatively strong one. But for such notions as strong or weak nations to be meaningful, they should be defined precisely in the context of the model, and it should be rationalized why they should matter for trade policy. ${ }^{17}$ Our analysis already incorporates considerations of country size to the extent that large countries will tend to have large markets and hence be net recipients of transfers since gaining access to their markets will tend to be more valuable to their trading partners than is the value of access to their smaller trading partners' markets. It is not obvious that country size should matter beyond this consideration. And most importantly, our approach of not introducing such notions of power or size beyond those of national markets is, at least formally, consistent with the GATT/WTO practice of "one country - one vote" where by "vote" we mean a country's ability to block some proposal.

\footnotetext{
${ }^{17}$ Doing so would not necessarily be difficult. It could involve incorporating additional considerations such as, for example, migration or international security. See Kowalczyk (2000).
} 
In reality, certain countries may yield more influence than others for reasons not captured in our discussion. ${ }^{18}$ Yet, formally, "votes" in GATT/WTO are not weighted by size or by share in world trade. ${ }^{19}$ We do not exclude that it would be useful to consider analytically different weightings of influence of nations in our model, and that doing so might lead to results on global free trade and customs unions that resemble what we in fact observe. However, we do believe that the approach we follow here of putting forth global free trade with transfers as the reference proposal to be blocked captures in essential ways several important features of the present multilateral trading system.

\footnotetext{
${ }^{18}$ For example, some members may devote more financial or diplomatic resources to the WTO than other members. Membership contributions to the WTO annual budget are a function of individual nations' share of world trade, and there is considerable concern over and efforts to improve the ability of developing countries to participate actively in WTO work and negotiations.

${ }^{19}$ In other multilateral institutions, such as the International Monetary Fund or the United Nations, some countries may have more voting power than others, or they may have permanent representation and veto power in councils or other fora. The Atlantic Council of the United States (1976) suggested in its GATT Plus proposal that assigning votes to contracting parties according to their share in world trade might enable GATT to work more efficiently.
} 


\section{Further Discussion of Results}

We motivated in the Introduction the general relevance of transfers to induce multilateral free trade. However, transfers might not always be necessary to obtain global free trade. It follows from expression (7) that if consumption and production gains from global free trade are so large that they more than offset any terms-of-trade losses, then a country would gain from global free trade even in the absence of transfers. Indeed, it is possible even be that no country would need a transfer to gain from global free trade. For example, little international trade in the status quo would tend to reduce the size of any terms of trade losses, and hence the need for compensation. And transfers might not be needed to induce global free trade if countries are relatively similar in size, since an offer of access to any country $i^{\prime}$ s market may then be sufficiently valuable to induce its trading partners to eliminate their trade barriers without requesting additional payments. ${ }^{20}$

We have derived our results for the standard model of international trade under perfect competition, which is also the model for which Ohyama (op. cit.), Kemp and Wan (op. cit.), and Grinols (op. cit.) established their

\footnotetext{
${ }^{20}$ Kowalczyk and Sjöström (1994) offer extensive discussion of when sidepayments are needed and when they are not for multilateral policy cooperation.
} 
findings. As shown by Kowalczyk and Sjöström (1994, 2000), in a model of international trade in monopoly goods, similar considerations and results hold under imperfect competition, including that transfers, if necessary to induce multilateral cooperation as an outcome in the core, will tend to go from those with much to gain from multilateral cooperation to those with little to gain from it.

While we have shown that a group of countries cannot agree to form a Kemp-Wan-Grinols customs union to manipulate their free trade payoffs, we have not established that countries would not seek to manipulate their status quo trade to obtain a higher payoff either in a customs union or in a subsequent situation of global free trade. Also, we do not consider cheating. For example, net recipients of transfers might, upon receipt of some agreed payment, renege on their part of an agreement and raise their tariffs back up to their initial levels - or they might even choose not to eliminate their tariffs in the first place. Our model is static, and all payments and tariff reductions occur simultaneously. However, these questions are important, and exploring them might cast light on certain practices in trade liberalization. ${ }^{21}$

\footnotetext{
${ }^{21}$ For example, as documented in Kowalczyk and Donald Davis (1998), countries in preferential and in multilateral agreements often choose to adjust their rates gradually and in tandem with their trading partners. This may be due to adjustment costs, or it may be to avoid, or at least reduce, any disruption from having to revert the process of
} 
We have assumed throughout the paper that national governments seek to maximize their own national income, which is the conventional approach in the theory of international economic integration. To the extent this fails to describe the economic, political, or institutional realities in nations, it might be appropriate instead to consider trade policy to be determined by interest groups as done, for example, by Gene Grossman and Elhanan Helpman (1995). Even so, international transfers, this time between interest groups or between parties located in different countries, might play a role.

We do not investigate in this paper whether national income maximizing governments would agree to the assumed institutional innovations, i.e., whether they would agree in the first place to restricting the tariffs of customs unions to be compensating to generate Kemp-Wan customs unions. Also, we do not consider whether there might be other formulae for transfers than the Grinols transfers that would support global free trade with compensation and, if so, whether countries might seek to negotiate over which of the implied financial mechanisms should be implemented. ${ }^{22}$

reductions and instead raise tariffs to punish some trade partners who have not upheld their end of the agreed tariff reductions. Richard Chisik (2003) and Kyle Bagwell and Robert Staiger $(1997 \mathrm{a}, \mathrm{b})$ demonstrate that self-enforcement may imply that tariff rates are phased out gradually.

${ }^{22}$ In their model of international monopoly trade, Kowalczyk and Sjöström (2000) identify two different formulae for sidepayments, each of which will make every government 
It is a property of the transfer mechanism considered here, and more generally of transfers that support the grand coalition, i.e., the situation where all participants cooperate with each other, that they tend to go from countries with much to gain from the grand coalition forming (here global free trade) to countries with little to gain. ${ }^{23}$ The transfers are, in effect, net payments to countries that would gain from breaking away from global free trade in return for their abstaining from doing so. The transfer payments may even go from low-income to high-income countries. This is unappealing, and could make such schemes difficult or even impossible to implement. However, it is important to recognize, that a country's aggregate net payment to other nations never exceeds that country's gains from free trade as compared to the status quo - in other words, if the transfers are viewed as the price a country would have to pay for multilateral free trade and thus for the associated welfare gains to that country, then the country would be willing to pay that price if doing so is necessary and if the gains to it from global free trade exceed that price. Also, it is possible that any objectives on income distribution would be better addressed through policies directly aimed at the

willing to enter into agreements with all other governments to restrict the domestic firm's mark-up prices in foreign markets. It is assumed, in that paper, that countries cannot affect which of these two fiscal mechanisms would be used.

${ }^{23}$ Kowalczyk and Sjöström (1994). 
distribution of income, such as, for example, foreign aid, than through trade policies. In any case, considerations regarding income distribution would be additional to the ones of the analysis in this paper, and they might well lead to different net payments between nations than those identified here. The transfers in this analysis are not simply transfers of income from one group of countries to another. Rather, they are payments from one group of countries to another group in return for the latter countries eliminating their tariffs. These transfers are a missing instrument that allows the elimination of otherwise immovable trade barriers.

Finally, we stress again the point made in the previous section, that the proposal we consider here of global free trade with transfers requires less information than forming Kemp-Wan-Grinols customs unions do. Free trade with Grinols transfers requires only information about countries' initial trade flows, which is available. In comparison, Kemp-Wan customs unions require not only information about countries' initial trade flows, but they require also an ability to forecast the implied changes in trade flows in order to calculate the compensating external tariff that will maintain these trade flows at their initial levels. Getting to global free trade with Grinols transfers in one step - with zero tariffs - would thus be easier from an information point of view 
than getting there via Kemp-Wan-Grinols customs unions.

\section{Conclusion}

In some widely cited work, Ohyama (op. cit.) and Kemp and Wan (op. cit.) argued that customs unions with compensating tariffs, i.e., customs unions that leave trade with non-members unaffected, would lead to global free trade. They were correct about this - but for a different reason than they proposed. As we show in this paper, in a world where customs unions are restricted to having no effect on non-members, countries would agree immediately to global free trade with Grinols transfers because the implied restrictions on tariffs and the existence of international income transfers would reduce the gains from not agreeing to global free trade with such transfers.

We conclude that Kemp-Wan-Grinols customs unions are even more favorable to the program of multilateralism than it was believed - they favor global free trade by never forming. Our analysis does not provide a direct explanation of the proliferation of free trade areas and customs unions but it does point at some potential reasons, including that Article XXIV currently

does not require that customs unions or free trade agreements be neutral with 
respect to non-members, and that many agreements, including multilateral ones, have no provisions for financial mechanisms.

\section{References}

[1] Atlantic Council of the United States, 1976, GATT Plus: A Proposal for Trade Reform, New York: Praeger.

[2] Bagwell, Kyle, and Robert W. Staiger, 1997a, "Multilateral Tariff Cooperation During the Formation of Customs Unions," Journal of International Economics 42, 91-123.

[3] Bagwell, Kyle, and Robert W. Staiger, 1997b, "Multilateral Tariff Cooperation During the Formation of Free Trade Areas," International Economic Review 38, 291-319.

[4] Chisik, Richard, 2003, "Gradualism in Free Trade Agreements: A Theoretical Justification," Journal of International Economics 59, 367-397.

[5] Ethier, Wilfred J., 2002, "Political Externalities, Nondiscrimination, and a Multilateral World," University of Pennsylvania, Department of Economics, December. 
[6] Gehrels, Franz, 1956-57, "Customs Unions from a Single-Country Viewpoint," Review of Economic Studies 24, 61-64.

[7] Grandmont, Jean-Michel, and Daniel McFadden, 1972, "A Technical Note on Classical Gains from Trade, Journal of International Economics $2,109-125$.

[8] Grinols, Earl L., 1981, “An Extension of the Kemp-Wan Theorem on the Formation of Customs Unions," Journal of International Economics 6, 95-97.

[9] Grinols, Earl L., and Kar-yiu Wong, 1991, "An Exact Measure of Welfare Change," Canadian Journal of Economics 24, 61-64.

[10] Grossman, Gene, and Elhanan Helpman, 1995, "The Politics of FreeTrade Agreements," American Economic Review 85, 667-690.

[11] Johnson, Harry G., 1953, "Optimum Tariffs and Retaliation," Review of Economic Studies 21, 142-153.

[12] Jones, Ronald W., 1969, "Tariffs and Trade in General Equilibrium: Comment," American Economic Review 59, 418-424. 
[13] Kemp, Murray C., and Henry Y. Wan, Jr., 1976, “An Elementary Proposition Concerning the Formation of Customs Union," Journal of International Economics 6, 95-97.

[14] Kennan, John, and Raymond Riezman, 1988, "Do Big Countries Win Tariff Wars?" International Economic Review 29, 81-85.

[15] Kennan, John and Raymond Riezman, 1990, "Optimal Tariff Equilibria with Customs Unions," Canadian Journal of Economics 23, 70-83.

[16] Konishi, Hideo, Carsten Kowalczyk, and Tomas Sjöström, 2003, "Global Free Trade Is in the Core of a Customs Union Game," May 2003.

[17] Kowalczyk, Carsten, 2000, "Welfare and Integration," International Economic Review 41, 483-494.

[18] Kowalczyk, Carsten, and Donald Davis, 1998, "Tariff Phase-Outs: Theory and Evidence from GATT and NAFTA," in Jeffrey A. Frankel, ed.: The Regionalization of the World Economy, Chicago: The University of Chicago Press.

[19] Kowalczyk, Carsten, and Tomas Sjöström, 1994, "Bringing GATT into the Core," Economica 61, 301-17. 
[20] Kowalczyk, Carsten, and Tomas Sjöström, 2000, "Trade as Transfers, GATT and the Core," Economics Letters 66, 163-169.

[21] Kowalczyk, Carsten, and Ronald Wonnacott, 1991, "Substitute and Complement Trading Clubs," Dartmouth College Department of Economics Working Paper No. 91-16.

[22] Kowalczyk, Carsten, and Ronald Wonnacott, 1992, "Hubs and Spokes and Free Trade in the Americas," NBER Working Paper No. 4198.

[23] Lipsey, Richard G., 1957, "The Theory of Customs Unions: Trade Diversion and Welfare," Economica 24, 40-46.

[24] Lipsey, Richard G., and Kelvin Lancaster, 1956, "The General Theory of Second Best," Review of Economic Studies 24, 11-32.

[25] Macho-Stadler, Inés, David Pérez-Castrillo, and Clara Ponsati, 1998, "Stable Multilateral Trade Agreements," Economica 65, 161-177

[26] Meade, James, 1955a, Trade and Welfare, London: Oxford University Press.

[27] Meade, James, 1955b, The Theory of Customs Unions, Amsterdam: North-Holland Publishing Company. 
[28] Ohyama, Michihiro, 1972, "Trade and Welfare in General Equilibrium," Keio Economic Studies 9, 73-73.

[29] Riezman, Raymond, 1985, "Customs Union and the Core," Journal of International Economics 19, 355-365.

[30] Vanek, Jaroslav, 1965, General Equilibrium of International Discrimination: The Case of Customs Unions, Cambridge: Harvard University Press.

[31] Viner, Jacob,1950, The Customs Union Issue, New York: Carnegie Endowment for International Peace.

[32] Wonnacott, Paul, and Ronald Wonnacott, 1981, "Is Unilateral Tariff Reduction Preferable to a Customs Union? The Curious Case of the Missing Foreign Tariffs," American Economic Review 71, 704-714.

[33] World Trade Organization, 1999, The Legal Texts: The Results of the Uruguay Round of Multilateral Trade Negotiations, Cambridge: Cambridge University Press. 